\title{
PENGGOLONGAN TEMA DALAM KARYA FIKSI
}

\author{
Nurhakiki ${ }^{1}$, Andreawan ${ }^{2)}$ \\ ${ }^{1,2)}$ Fakultas Sastra, Universitas Muslim Indonesia \\ Jalan Urip Sumoharjo KM 5, Makassar \\ nurhakiki171099@gmail.com ${ }^{1)}$,gecolandre@gmail.com ${ }^{2)}$
}

\begin{abstract}
Abstrak: Tema merupakan dasar gagasan, ide, pokok, pikiran yang dituangkan pengarang dalam karyanya, baik secara tersurat maupun secara tersirat. Suatu novel harus diawali dengan gagasan yang akan dikembangkan sebagai sebuah cerita yang utuh. Begitu pula dengan ide yang akan dituangkan dalam cerita: ide tentang keterbelakangan sosial, pendidikan yang tertinggal, religi, persoalan HAM. Tema berfungsi sebagai dasar pengembangan seluruh cerita. Oleh karena itu, tema terkait dengan seluruh bagian cerita. Secara prinsip, tema terdiri atas dua macam, yaitu tema utama merupakan makna tambahan yang menyokong dan mencerminkan makna pokok cerita. Tema merupakan suatu gagasan sentral, sesuatu yang hendak diperjuangkan dalam suatu tulisan atau karya fiksi. Tema adalah inti permasalahan yang hendak dikemukakan pengarang dalam karyanya. Oleh sebab itu, tema merupakan hasil konklusi dari berbagai peristiwa yang terkait dengan penokohan dan latar. Jadi dapat disimpulkan bahwa tema, yaitu suatu pokok atau inti persoalan yang mendasari suatu cerita. Untuk menemukan sebuah tema dalam sebuah karya fiksi, ia haruslah disimpulkan dari keseluruhan cerita, tidak hanya berdasarkan bagian-bagian tertentu dari cerita walau tema sulit ditemukan secara pasti, ia bukanlah makna yang "disembunyikan", walau belum tentu juga dilukiskan secara eksplisit.
\end{abstract}

Kata kunci: penggolongan, tema, karya fiksi

\section{PENDAHULUAN}

Tema merupakan dasar gagasan, ide, pokok, pikiran yang dituangkan pengarang dalam karyanya, baik secara tersurat maupun secara tersirat. Suatu novel harus diawali dengan gagasan yang akan dikembangkan sebagai sebuah cerita yang utuh. Begitu pula dengan ide yang akan dituangkan dalam cerita: ide tentang keterbelakangan sosial, pendidikan yang tertinggal, religi, persoalan HAM.

Tema berfungsi sebagai dasar pengembangan seluruh cerita. Oleh karena itu, tema terkait dengan seluruh bagian cerita. Secara prinsip, tema terdiri atas dua macam, yaitu tema utama merupakan makna tambahan yang menyokong dan mencerminkan makna pokok cerita.
Struktur oposisional pada level individu terbagi atas: oposisi antara kemauan dengan keinginan, oposisi antara perasaan dengan pikiran, oposisi antara cinta dengan kewajiban, oposisi antara kehidupan dengan harga diri. Struktur oposisional pada level sosial terbagi atas: oposisi antara individu dengan masyarakat dan oposisi antara pekerja dengan pemilik modal. Struktur oposisional pada level sosial terbagi atas: oposisi antara cobaan dengan keimanan dan oposisi antara dosa dengan pahala.

Semi (1984:35) menyatakan bahwa tema merupakan suatu gagasan sentral, sesuatu yang hendak diperjuangkan dalam suatu tulisan atau karya fiksi. Sedangkan Muhardi dan Hasanuddin (1982:8) menyatakan bahwa tema adalah inti 
permasalahan yang hendak dikemukakan pengarang dalam karyanya.

Oleh sebab itu, tema merupakan hasil konklusi dari berbagai peristiwa yang terkait dengan penokohan dan latar. Jadi dapat disimpulkan bahwa tema, yaitu suatu pokok atau inti persoalan yang mendasari suatu cerita.

Untuk menemukan sebuah tema dalam sebuah karya fiksi, ia haruslah disimpulkan dari keseluruhan cerita, tidak hanya berdasarkan bagian-bagian tertentu dari cerita (Nugiantoro, 1995:68) walau tema sulit ditemukan secara pasti, ia bukanlah makna yang "disembunyikan", walau belum tentu juga dilukiskan secara eksplisit.

\section{PEMBAHASAN}

Tema adalah hantu. Ia ada tetapi tak terlihat. Kita serasa ditemaninya saat membaca sebuah novel sampai selesai dan baru menampakkan diri sekilas di pikiran kita saat kita benar-benar memikirkannya. Adler dan Doren (2012:229) mengatakan bahwa menganalisis keindahan lebih sulit daripada kebenaran faktual.

Ketika kita mempertanyakan makna sebuah karya maka sama halnya dengan kita mempertanyakan tema dari karya tersebut. Tema yang jelas akan membantu kita dalam usaha penafsiran dan pendeskripsian makna dari sebuah karya fiksi. Tema, menurut Stanton (1965:20) dan Kenny (1966:88) adalah makna yang dikandung oleh sebuah cerita.

Hartoko dan Rahmanto (1986:142) mengatakan tema adalah gagasan dasar umum yang menopang sebuah karya sastra dan yang terkandung di dalam teks sebagai struktur semantis dan yang mengangkat persamaan-persamaan atau perbedaan- perbedaan. Sementara Baldic (2001:258) mendefinisikan tema sebagai gagasan abstrak utama yang terdapat dalam sebuah karya sastra atau yang secara berulangulang dimunculkan baik secara eksplisit maupun implisit lewat pengulangan motif.

Jika dua pendapat digabungkan, maka tema adalah gagasan dasar umum yang menopang sebuah karya sastra sebagai struktur semantis dan bersifat abstrak yang secara berulang-ulang dimunculkan lewat motif-motif dan biasanya dilakukan secara implisit. Atau singkatnya, tema adalah makna yang dikandung sebuah cerita (Kenny, 1966:88).

Tema merupakan gagasan dasar umum yang menopang sebuah karya sastra dan yang terkandung di dalam teks sebagai strukutur semantis dan yang menyangkut persamaan-persamaan atau perbedaanperbedaan. Tema menjadi pengembangan seluruh cerita, maka ia pun bersifat menjiwai seluruh bagian cerita itu. Berdasarkan kriteria bahwa makna utama (baca: tema pokok) bersifat merasuki keselurahan cerita.

Menurut Stanton (1965:21), tema adalah makna sebuah cerita yang secara khusus menerangkan sebagian besar unsurnya dengan cara sederhana. Dengan kata lain, tema kurang lebih dapat bersinonim dengan ide utama dan tujuan utama.

Dengan demikian tema dapat dipandang sebagai dasar cerita, gagasan dasar umum, sebuah karya novel. Gagasan dasar umum inilah yang tentunya telah ditentukan sebelumnya oleh pengarang yang dipergunakan untuk mengembangkan sebuah cerita.

Tema dalam sebuah karya sastra, fiksi hanyalah merupakan salah satu dari sejumlah unsur pembangun cerita yang lain, yang secara bersama membentuk sebuah 
keseluruhan. Tema sebuah cerita tidak mungkin disampaikan secara langsung, melainkan hanya secara implisit melalui cerita. Unsur-unsur ceria yang lain, khususnya oleh Stanton dikelompokkan sebagai fakta cerita-tokoh, plot, latar-yang bertugas mendukung dan menyampaikan tema tersebut.

Bahkan sebenarnya, eksistensi tema itu sendiri amat bergantung dari berbagai unsur yang lain. Hal itu disebabkan karena tema yang notabene "hanya" berupa makna atau gagasan dasar umum suatu cerita, tak mungkin hadir tanpa unsur bentuk yang menampungnya.

Dengan demikian, sebuah tema baru akan menjadi makna cerita jika ada dalam keterkaitannya dengan unsur-unsur cerita yang lain. Tema sebuah cerita tidak mungkin disampaikan secara langsung, melainkan hanya secara implisit melalui cerita.

Unsur-unsur cerita yang lain, khususnya yang oleh Stanton dikelompokan sebagai fakta, cerita, tokoh, plot, latar yang bertugas mendukung dan menyampaikan tema tersebut. Tema bersifat memberi koherensi dan makna terhadap keempat unsur tersebut dan juga berbagai unsur fiksi yang lain.

\section{Penggolongan Tema}

Tema dapat digolongkan ke dalam beberapa kategori yang berbeda tergantung dari segi mana penggolongan itu dilakukan. Pengkategorian tema yang akan dikemukakan berikut dilakukan berdasarkan 3 sudut pandang, yaitu penggolongan dikotomi yang bersifat tradisional dan nontradisional, penggolongan dilihat dari tingkat pengalaman jiwa menurut Shipley, dan penggolongan dari tingkat keutamaannya.

\section{Tema Tradisional dan Nontradisional}

Tema tradisional adalah tema yang sering dipakai para pembuat cerita. Tema tradisional dimaksudkan sebagai tema yang menunjuk kepada tema yang hanya itu-itu saja, dalam arti ia telah lama dipergunakan dan dapat ditemukan dalam berbagai cerita termasuk cerita lama. Pernyataan-pernyataan tema yang dapat dipandang sebagai tema yang bersifat tradisional misalnya:

a. Kebenaran dan keadilan mengalahkan kejahatan

b. Cinta yang sejati menuntut pengorbanan

c. Setelah menderita orang baru teringat Tuhan

d. Berakit-rakit ke hulu, berenang-renang ke tepian

Tema tradisional merupakan tema yang sudah sering diungkapkan, bahkan berulang-ulang. Artinya, tema tersebut telah lama dipergunakan dan terdapat hamper dalam berbagai cerita, termasuk cerita lama, sehingga daya tariknya terasa berkurang.

Tema-tema tradisional walau banyak variasinya boleh dikatakan selalu ada kaitan dengan masalah kebenaran dan kejahatan (Meredith \& Fitzgerald, 1972:66). Pada umumnya tema-tema tradisional merupakan yang digemari orang dengan status sosial apapun, dimanapun, dan kapanpun. Hal itu disebabkan karena pada dasarnya setiap orang cinta akan kebenaran dan membenci sesuatu yang sebaliknya.

Selain hal-hal yang bersifat tradisional, tema sebuah karya mungkin saja mengangkat sesuatu yang tidak lazim atau dikatakan bersifat nontradisional. Karena sifatnya yang nontradisional, tema yang demikian mungkin tidak sesuai dengan harapan pembaca, bersifat melawan arus, mengejutkan, bahkan boleh jadi mengesalkan, mengecewakan atau berbagai afektif yang lain. 
Berhadapan dengan cerita fiksi, pada umumnya orang mengharapkan yang baik, yang jujur, atau semua tokoh yang digolongkan sebagai protagonist, akhirnya mengalami kemenangan kejayaan. Novel Kemelut Hidup karya Ramadhan K.H, misalnya menampilkan tema yang bersifat melawan arus tersebut, kejujuran yang justru menyebabkan kehancuran.

\section{Tingkatan Tema Menurut Shipley}

Dalam Dictionary of World Literature (1962:417), Shipley mengartikan tema sebagai subjek wacana, topik umum, atau masalah utama yang dituangkan ke dalam cerita. Shipley membedakan tematema karya sastra ke dalam tingkatantingkatan semuanya ada lima tingkatan berdasarkan tingkatan pengalaman jiwa.

\section{Tema Tingkat Fisik}

Tema yang satu ini memfokuskan diri pada kegiatan fisik. Ciri dari karya yang memiliki tingkatan tema ini adalah cerita yang mempunyai porsi lebih banyak membicarakan hal yang berhubungan dengan kegiatan fisik atau jasmani. Penggambaran emosi tokoh dalam cerita yang berada pada tingkatan ini sangat sukar dijumpai, jika pun ada hanya sedikit saja.

Sesuai dengan namanya fisik, maka cerita dengan tema ini lebih menonjolkan hal-hal yang berhubungan dengan fisik. Cerita-cerita karangan Bastian Tito (Wiro Sableng) atau Asmaraman S Kho Ping Hoo tentu sudah sangat melegenda bagi pembaca cerita silat.

Manusia sebagai (atau: dalam tingkat kejiawaan) molekul, man as molecule. Tema karya sastra pada tingkat ini lebih banyak menyaran dan ditunjukkan oleh banyaknya aktivitas fisik daripada kejiwaan. Unsur latar dalam novel dengan tema tingkat ini mendapat penekanan. Contoh: Around the World in Eighty Day karya Julius Verne.

\section{Tema Tingkat Organik}

Cerita yang berada pada level ini mengangkat cerita yang berorientasi pada kegiatan seksual manusia. Dalam tingkatan ini cerita lebih banyak mengangkat mengenai kehidupan paling intim manusia baik itu mengenai rutinitas seksual ataupun penyimpangan seksual.

Tema ini menonjolkan seksualitas (biasanya explisit). Untuk memahami tema ini, silakan baca novel-novel Ayu Utami, seperti Saman, Bilangan Fu, dan Larung. Tak luput juga tema lesbian seperti karya Herlinatiens (Garis Tepi Seorang Lesbian), dan homoseksual karya Rangga, The Sweet Sin.

Manusia sebagai (atau: dalam tingkat kejiwaan) protoplasma, man as protoplasm. Tema karya sastra tingkat ini lebih banyak menyangkut dan atau mempersoalkan masalah seksualitas suatu aktivitas yang hanya dapat dilakukan oleh makhluk hidup.

Berbagai persoalan seksual manusia mendapat penekanan dalam novel dengan tema ini, khususnya yang bersifat menyimpang, misalnya berupa penyelewengan dan pengkhianatan suami istri atau skandal seksual yang lain. Contoh: Senja di Jakarta, Tanah Gersang, Maut dan Cinta karya Mochtar Lubis.

\section{Tema Tingkat Sosial}

Tema yang berada pada tingkat ini mulai membicarakan kehidupan sosial si tokoh. Lingkungan dan strata sosial sangat pekat dan sangat ada dalam cerita yang barada pada tingkatan ini. Masalah ekonomi dan politik sangat getol dibicarakan pada tingkatan ini. Dalam tingkatan ini manusia digambarkan sebagai makhluk sosial. 
Tema ini paling banyak ditulis. Berisi konflik-konflik yang sering terjadi di masyarakat. Tengok Laskar Pelangi karya Andrea Hirata tentang konflik di dunia pendidikan atau Ronggeng Dukuh Paruk karya Ahmad Tohari yang berisi suka duka seorang ronggeng hidup pada masyarakat di sekitar tempat tinggalnya.

Manusia sebagai makhluk sosial, man as socious. Objek dari tema ini adalah kehidupan bermasyarakat yang merupakan tempat aksi interaksinya manusia dengan sesama dan dengan lingkungan alam mengandung banyak permasalahan dan konflik, antara lain masalah sosial, ekonomi, politik, pendidikan, kebudayaan, percintaan, dll. Contoh: Kubah, Ronggeng Dukuh Paruk, Kemelut Hidup, dll.

\section{Tema Tingkat Egoik}

Pada tingkatan ini sebuah cerita sudah mencapat kehalusan yang di atas ratarata. Bagi para pembaca pemula kadang agak sulit untuk mencerna cerita yang berada pada tingkatan egoik. Pada tingkatan ini tema yang diangkat merupakan tingkat individualis yang sangat kental. Penuntutan hak atas diri pribadi sangat banyak dibicarakan di sini.

Tema ini lebih menonjolkan bagaimana sikap individu dalam menyikapi permasalahannya. Sikap tersebut mencangkup sikap batin Sang Tokoh yang berhubungan dengan egoisitas, harga diri atau martabat. Saya jadi ingat Perempuan Kembang Jepun karya Lan Fang.

Manusia sebagai individu, man as individualism. Di samping sebagai makhluk sosial, manusia sekaligus juga sebagai makhluk individu yang senantiasa menuntut pengakuan atas hak individualitasnya.

Dalam kedudukan itulah, manusia punya banyak permasalahan dan konflik, misalnya egoisitas, martabat, harga diri, dan lain-lain yang pada umumnya bersifat batin. Contoh novel: Atheis, Jalan Tak Ada Ujung, Gairah untuk Hidup dan untuk Mati, dan sebagainya.

\section{Tema Tingkat Divine}

Pada tahap ini kehalusan dan keruncingan sudah mencapai batas akhir. Dalam tingkatan tema devina manusia sudah mulai membicarakan penciptanya. Renungan yang sangat mendalam dapat kita dapatkan dalam tingkatan tema divine.

Tema religi dan memakai filosofifilosofi termasuk jenis tema Divine. Novelnovel karya Habiburraman El Shirazy atau novel semacam Dunia Sophie milik Jostein Gaarder adalah contoh tema divine.

Manusia sebagai makhluk tingkat tinggi yang belum tentu setiap manusia mengalami dan atau mencapainya. Masalah yang menonjol dalam tema ini adalah masalah hubungan manusia dengan Sang Pencipta, masalah religiositas atau yang bersifat filosofis seperti pandangan hidup, visi, dan keyakinan. Contoh novel: Robohnya Surau Kami, Datangnya dan Perginya, dan Kemarau karya Navis.

Tema-tema diatas tidak bersifat eksklusif menguasai novel. Bisa saja sebuah novel mempunyai lebih dari satu tema diatas. Contoh, Bilangan $F u$, disamping tema tipe organik, dia juga bisa masuk tingkat divine.

\section{Tema Utama dan Tema Tambahan}

Pada hakikatnya tema merupakan makna yang dikandung cerita. Makna dalam suatu cerita mungkin saja lebih dari satu interpretasi. Hal inilah yang menyebabkan tidak mudahnya kita menentukan tema pokok cerita atau yang disebut tema mayor.

Tema mayor adalah makna pokok cerita yang menjadi dasar atau gagasan dasar 
umum suatu karya. Menentukan tema mayor pada hakikatnya merupakan aktivitas memilih, mempertimbangkan dan menilai di antara sejumlah makna yang ditafsirkan ada dikandung oleh karya bersangkutan.

Makna pokok cerita tersirat dalam sebagian besar cerita tersirat dalam sebagian besar cerita namun tidak dapat dikatakan dalam keseluruhan. Tema mayor adalah makna pokok cerita yang menjadi dasar atau gagasan dasar umum karya tersebut, atau bisa juga disebut tema yang paling utama.

Makna yang hanya terdapat pada bagian tertentu cerita dapat diidentifikasikan sebagai makna tambahan. Makna-makna tambahan inilah yang disebut sebagai tema minor. Tema minor adalah makna yang terdapat pada bagaian cerita atau bisa disebut sebagai tema sebagaian. Dengan demikian banyak sedikitnya tema minor tergantung pada banyak sedikitnya makna tambahan yang dapat ditafsirkan dari sebuah cerita novel.

Dengan demikian, banyak sedikitnya tema minor tergantung dari kuantitas makna tambahan yang dapat ditafsirkan. Penafsiran makna itu haruslah dibatasi pada maknamakna yang terlihat menonjol, di samping mempunyai bukti-bukti konkret pada karya itu.

Tema tidak hanya bersifat tunggal dalam sebuah novel. Disamping tema utama, tidak jarang kita juga menemui tema sampingan alias tema minor. Untuk menentukan tema tersebut maka diperlukan aktifitas mengindentifikasi, memilih, mempertimbangkan dan menilai diantara sejumlah makna yang akan ditafsirkan.

Makna mayor harus terdapat disiratkan pada keseluruhan cerita, bukan hanya sebagian saja (makna minor). Makna ini harus dapat dibuktikan terdapat pada karya tersebut (bukan ngawur) dan terlihat dominan. Makna minor harus terlihat mendukung atau mendukung keberadaan makna mayor. Kesimpulannya, makna tambahan atau makna minor bersifat mempertegas eksistensi makna utama atau makna mayor.

Stanton (1965:22-23) memberikan kriteria agar dapat menafsirkan karya fiksi sebagai berikut:

1. Penafsiran harus memperhatikan detil cerita. Ini adalah bagian yang melelahkan dalam menafsirkan sebuah tema, apalagi jika novel tersebut panjang. Namun biasanya dapat disiasati dengan memperhatikan konflik utama. Pada konflik utama biasanya sering terletak tema utama.

2. Penafsiran tidak boleh bertentangan dengan detil cerita. Alangkah anehnya suatu novel jika masing-masing detilnya bertentangan satu sama lain. Sebagai media penyampaian pikiran penulis harusnya hal demikian tidak terjadi, sehingga pada saat menarik kesimpulan sebuah tema kita harus memastikan kesimpulan tersebut tidak bertentangan dengan bagian-bagian cerita yang lain.

3. Penafsiran tidak boleh mendasarkan diri pada hal yang tidak dinyatakan baik secara langsung maupun tidak langsung. Jangan mengira-ngira! Semua harus ada penjelasannya. Dalam arti lain harus ada bukti empiris.

4. Penafsiran harus berdasarkan buktibukti baik yang dinyatakan secara langsung maupun yang disarankan dalam cerita. Penafsiran harus terdapat dalam kata, alinea, dialog maupun penafsiran dari tulisan dalam novel tersebut yang sekiranya mencerminkan tema yang sedang ditafsir. Kriteria ke-4 ini adalah penjelas dari kriteria ke-3 diatas.

\section{PENUTUP}

Tema dapat digolongkan ke dalam beberapa kategori yang berbeda tergantung 
dari segi mana penggolongan itu dilakukan. Pengkategorian tema yang akan dikemukan berikut dilakukan berdasarkan tiga sudut pandang, yaitu penggolongan dikotomi yang bersifat tradisional dan nontradisional, penggolongan dilihat dari tingkat pengalaman jiwa menurut Shipley, dan penggolongan dari tingkat keutamaannya. Tema digolongkan menjadi sudut pandang, yaitu penggolongan tema tradisional dan nontradisional. Tingkatan tema menurut Shipley, tema utama dan tema tambahan.

\section{DAFTAR PUSTAKA}

Back, Dion. 2014. Kajian Prosa Fiksi. http://dionback7.blogspot.com/2014/12/kajian-prosafiksi-tema.html

Fitrianto, Fajar. 2017. Tema dalam Fiksi. http://fajarfitrianto.hol.es/?p=503

Jimbe, Haris. 2013. Unsur Intrinsik Prosa Fiksi. http://harisjimbe.blogspot.com/2013/03/unsur-intrisik-prosa-fiksi.html

Mansyur, Umar. 2016. Pemanfaatan Nilai kejujuran dalam Cerpen sebagai Bahan Ajar Berbasis Pendidikan Karakter. In Mengais Karakter dalam Sastra (pp. 330-339). https://doi.org/10.17605/osf. io/z4t3y

Mansyur, Umar. 2018. Kiat dan Teknik Penulisan Skripsi bagi Mahasiswa. INA-Rxiv. https:://doi.org/10.31227/osf.io/juds7.

Muliadi, 2017. Buku Ajar Telaah Pros: Sebuah Terapan. Makassar: De La Macca.

Nawi. 2017. Pengertian Jenis dan Tingkatan Tema dalam Penulisan. https://www.pondokbelajar.com/2017/03/pengertian-jenis-dan-tingkatan-tema.html

Nurgiyantoro, Burhan. 2015. Teori Pengkajian Fiksi. Yogyakarta: Gadjah Mada University Press.

Ocitamala. 2018. Mengenal Tema dalam Karya Fiksi. http://dionback7.blogspot.com/2014/12/kajian-prosa-fiksi-tema.html

Wikipedia. 2018. Fiksi. https://id.wikipedia.org/wiki/Fiksi

Writer, Spot. 2014. Hakikat Tema dan Tingkatan Tema Menurut Shipley. http://spotwriter.blogspot.com/2014/12/hakikat-tema-dan-tingkatan-tema-menurut.html 